\title{
Assessment of TRH as a Potential MSH Release Stimulating Factor in Xenopus laevis
}

\author{
B. M. LIDY VERBURG-VAN KEMENADE,* BRUCE G. JENKS, ${ }^{*}$ THEO J. VISSER, $†$ \\ MARIE CHRISTINE TONON $\$$ AND HUBERT VAUDRY $\$$ \\ *Department of Zoology, Faculty of Science, Catholic University \\ Toernooiveld, 6525 ED Nijmegen, The Netherlands \\ $\dagger$ Department of Internal Medicine III and Clinical Endocrinology, Medical Faculty \\ Erasmus University, Rotterdam, The Netherlands \\ and $\ddagger$ Groupe de Recherche en Endocrinologie Moleculaire, Faculte des Sciences \\ Universite de Rouen, 76130 Mont-Saint-Aignan, France
}

Received 8 September 1986

\begin{abstract}
VERBURG-VAN KEMENADE, B. M. L., B. G. JENKS, T. J. VISSER, M. C. TONON AND H. VAUDRY. Assessment of TRH as a potential MSH release stimulating factor in Xenopus laevis. PEPTIDES 8(1) 69-76, 1987.-This study considers the possible involvement of the tripeptide TRH (thyrotropin releasing hormone) in the physiological regulation of melanophore stimulating hormone (MSH) secretion from the pars intermedia of the toad, Xenopus laevis. TRH was shown to stimulate release of MSH from superfused neurointermediate lobes obtained from white-background adapted animals, but had no effect on secretion from lobes of black-background adapted animals. Immunohistochemical analysis revealed a rich TRH-containing neuronal network terminating in the neural lobe of the Xenopus pituitary. Plasma levels of TRH, determined with a specific radioimmunoassay, proved to be extremely high and no significant difference in this level could be found between white- and black-adapted animals. Plasma TRH probably originates from the skin, and our results show that its concentration is within the effective concentration range established for this peptide in stimulating MSH release from the pars intermedia. Therefore, while both our superfusion and immunohistochemical results argue favourably for a function of TRH in the regulation of MSH secretion, we conclude that, in any regulatory role, it would likely have to function within the pars intermedia at concentrations exceeding the high plasma values. While TRH could be involved in short-term activation of the secretory process in white-background adapted animals or in animals undergoing the initial stages of black background adaptation, our results indicate that this peptide may have no function in the maintenance of secretion from the pars intermedia of animals fully adapted to black background.
\end{abstract}

Pars intermedia MSH TRH Regulation of secretion

THE pars intermedia of the pituitary gland synthesizes a precursor protein, proopiomelanocortin (POMC), from which melanophore stimulating hormone (MSH) and other peptides are derived (for reviews see $[9,12]$ ). In amphibians, MSH is released from the intermediate lobe of animals placed on a black background. This hormone stimulates the dispersion of pigment in dermal melanophores and consequently the skin displays a dark color. An important component in hypothalamic regulation of MSH secretion is an inhibitory mechanism, achieved by classical neurotransmitters such as dopamine $[8,9,20,24,37,39]$ and in the species Xenopus laevis at least, GABA [44]. Electronmicroscopical studies have revealed that the amphibian neurointermediate lobe is innervated by both classical neurons, and neurons of peptidergic nature $[14,28]$. In the frog, Rana ridibunda, the tripeptide pGlu-His-Pro $\left(\mathrm{NH}_{2}\right)$, which is the mammalian thyrotropin releasing hormone (TRH), has been shown to be very potent in stimulating $\mathrm{MSH}$ release from the pars inter- media [38]. In two species of Rana (Rana catesbeiana and $R$ ana ridibunda), immunohistochemical studies indicate the presence of a TRH-containing neuronal network within the pars intermedia $[27,32]$. Taken together, the above studies indicate that TRH of hypothalamic origin could be a physiological factor involved in the stimulation of MSH secretion. Amphibians are known, however, to have high plasma levels of TRH, which probably originate from the skin [16]. Plasma TRH could conceivably also be involved in the regulation of MSH secretion. Therefore plasma values of TRH should be considered in evaluation of a possible physiological function for this neuropeptide in amphibians. The purpose of the present study was to examine if this peptide could represent a physiological MSH-releasing factor in the toad Xenopus laevis. For this purpose we have: (1) determined the effect of TRH on MSH release from superfused neurointermediate lobes, (2) conducted immunocytochemical analysis and radioimmunoassays (RIA) to determine if this tripeptide is 

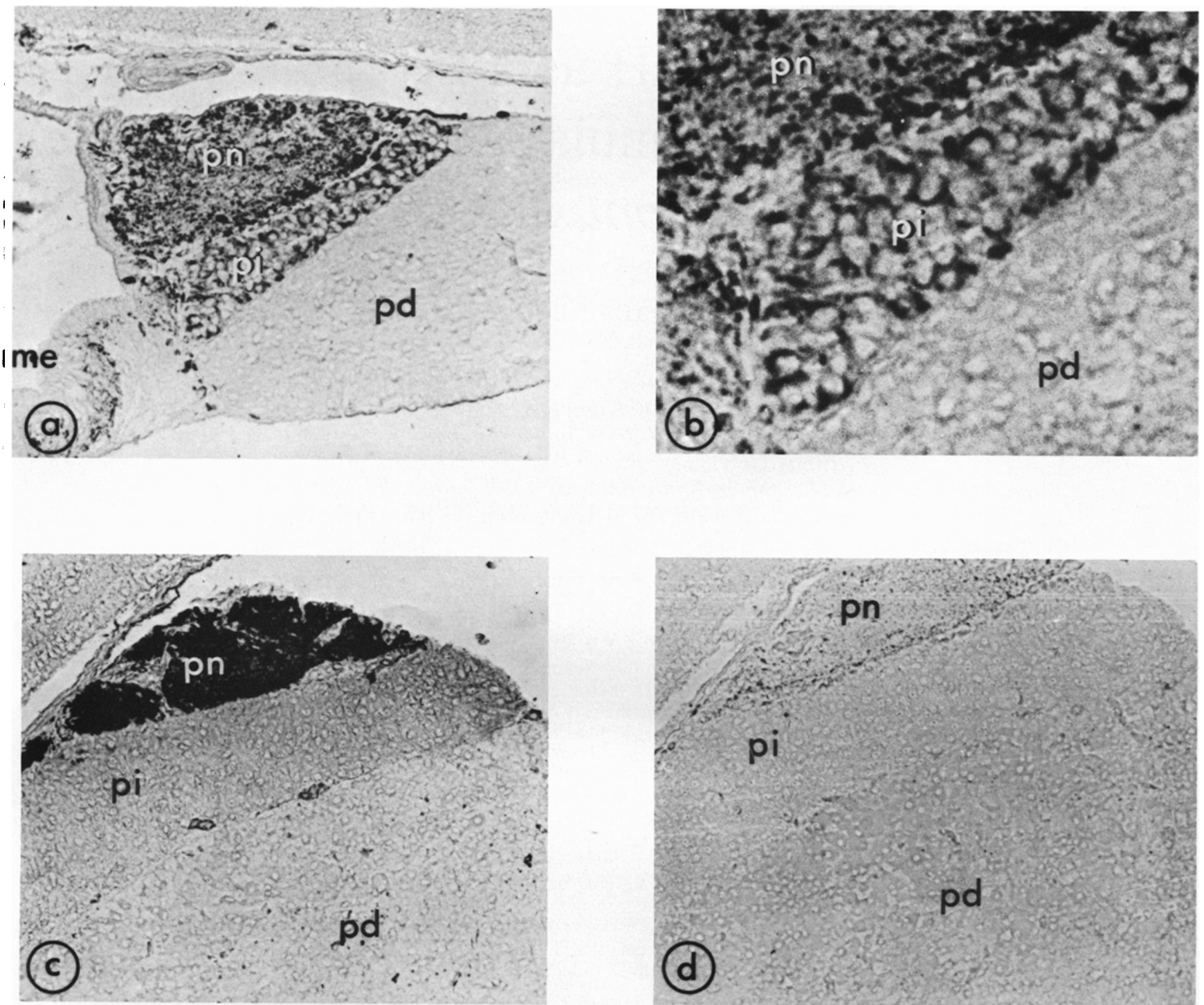

FIG. 1. TRH immunocytochemistry of the pituitary gland of Xenopus laevis. (a) Anti-TRH staining in pituitary gland of a white-background adapted animal shown at $135 \times$ magnification and (b) shown at $430 \times$ magnification. The anti-TRH staining in the pituitary gland of a black-background adapted animal is shown in (c) at $190 \times$ magnification and (d) represents the immunoabsorbed control. pn, pars nervosa; pi, pars intermedia; pd, pars distalis; me, median eminence; po, preoptic nucleus.

TABLE 1

TRH VALUES IN NEUROINTERMEDIATE LOBE, PARS DISTALIS AND PLASMA OF BOTH BLACKAND WHITE-BACKGROUND ADAPTED Xenopus laevis

\begin{tabular}{|c|c|c|c|}
\hline & & Black & White \\
\hline Neurointermediate lobe & ng/lobe & $0.871 \pm 0.063(n=7)$ & $0.800 \pm 0.063(n=7)$ \\
\hline Pars distalis & ng/lobe & $0.104 \pm 0.013(n=41)$ & $0.041 \pm 0.036(n=16)$ \\
\hline Plasma & $\mathrm{ng} / \mathrm{ml}$ & $\pm 4.6 \quad(n=47)$ & $\pm 8.2 \quad(n=13)$ \\
\hline
\end{tabular}




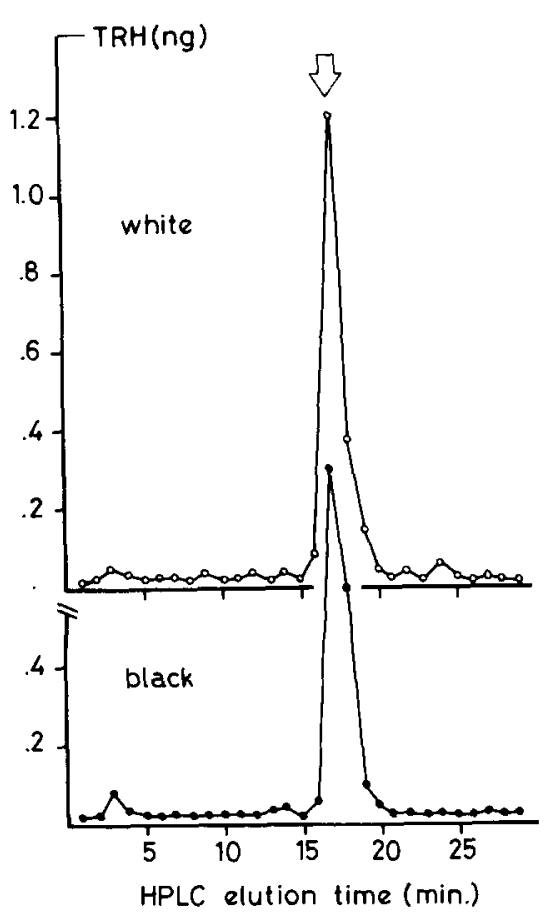

FIG. 2. HPLC analysis of TRH immunoreactive material in plasma from white- and black-background adapted Xenopus laevis. Fifty $\mu$ l of plasma extract were submitted to HPLC and analyzed by radioimmunoassay. Arrow indicates the elution position of synthetic pGlu-His-Pro- $\mathrm{NH}_{2}$.

present in the neurointermediate lobe, and (3) analyzed plasma levels of this peptide in relation to the color of background to which the animals are adapted.

\section{METHOD}

\section{Animals}

Xenopus laevis were bred and reared in the aquatic facility of the Department of Zoology, Catholic University, Nijmegen, The Netherlands. Animals were adapted to a black or white background for four weeks under a constant illumination at $22^{\circ} \mathrm{C}$. Degree of pigment dispersion was determined according to the melanophore index scale of Hogben and Slome [13].

\section{Immunocytochemistry With Anti-TRH}

Brain and pituitary tissue was fixed in Bouin-Hollande, paraplast embedded and $5 \mu \mathrm{m}$ sections were submitted to immunostaining with the peroxidase-anti-peroxidase method according to Sternberger [35] with 4-Cl-naphtol as oxygen acceptor. The antiserum 1:100 or 1:200 No. 4619 was characterized earlier $[46,47]$. Control experiments were performed after adsorption of the antiserum with TRH coupled to activated $\mathrm{CNBr}$ sepharose $4 \mathrm{~B}[42]$.

\section{TRH Extraction of Plasma and Pituitary Tissue}

Plasma samples. To 1 volume of trunk blood, 4 volumes of cold $100 \%$ ethanol were immediately added. After vigorous shaking it was left overnight at $4^{\circ} \mathrm{C}$, the supernatant was dried under nitrogen and redissolved in buffer in preparation for the radioimmunoassay (RIA) for TRH. The TRH im- munoreactive material found in the plasma was analyzed by reverse phase HPLC using a $100 \times 3 \mathrm{~mm} C P$-Spher $\mathrm{C}_{18}$ column (Chrompack, Middelburg, The Netherlands). Elution was performed with a linear gradient of $0-20 \%$ acetonitrite in $0.01 \mathrm{M}$ sodium phosphate $(\mathrm{pH} 7.7)$. Solvent flow was 0.6 $\mathrm{ml} / \mathrm{min}$ and $1 \mathrm{~min}$ fractions were collected. TRH content was determined in duplicate in $100 \mu$ l samples of each fraction.

Pituitary samples. The freshly dissected pituitary gland was separated into neurointermediate lobe and distal lobe. Each lobe was homogenized in $500 \mu$ l of cold $90 \%$ methanol in a glass potter, centrifuged for $2 \mathrm{~min}$ at $10,000 \mathrm{~g}$, and the supernatant was dried under nitrogen. The dried extract was dissolved in buffer for RIA determination of TRH.

\section{In vitro Superfusion of Neurointermediate Lobe Tissue}

Superfusion was performed in a system containing four independent superfusion chambers (volume $10 \mu \mathrm{l}$ each). Each neurointermediate lobe was placed in a chamber and incubation medium ( $112 \mathrm{mM} \mathrm{NaCl}, 2 \mathrm{mM} \mathrm{KCl}, 2 \mathrm{mM} \mathrm{CaCl}$, $15 \mathrm{mM}$ Hepes pH 7.38, $0.3 \mathrm{mg} / \mathrm{ml}$ BSA, $2 \mathrm{mg} / \mathrm{ml}$ glucose and carbogen aerated) was pumped through the chambers at a rate of $1.5 \mathrm{ml} / \mathrm{hr}$ at $22^{\circ} \mathrm{C}$. Fractions of $7.5 \mathrm{~min}$ were collected and stored at $-20^{\circ} \mathrm{C}$ until submission to radioimmunoassay for MSH. Experiments were conducted in two-, three- or four-fold. The results are expressed as a percentage of basal secretion; $100 \%$ basal secretion being defined as the average MSH value measured in several superfusion fractions before secretagogue addition. The fractions used in these calculations are given in the captions to the figures. Results of individual experiments were averaged and SEM values were calculated.

\section{Radioimmunoassays}

RIA for TRH. TRH was measured using antiserum produced against a TRH-dinitrophenylene-protein immunogen. Specificity characteristics have previously been described $[46,47]$. The antiserum was used at a final dilution of 1:20,000 and the assay was sensitive to $1 \mathrm{pg}$ per tube. The RIA does not measure the major TRH-metabolite pGluHis-Pro-OH nor the dipeptide fragment His-Pro-diketopiperazine. Precipitation of antibody-bound radioactivity was performed with second antibody in the presence of $2.5 \%$ polyethylene glycol. TRH was measured in duplicate.

RIA for $\alpha$ MSH. $\alpha \mathrm{MSH}$ was determined with an antiserum produced and characterized by Vaudry et al. [43]. The antiserum was used at a final dilution of 1:40,000. It has equal sensitivity towards des-N $\alpha$-acetyl- $\alpha \mathrm{MSH}$ and $\alpha \mathrm{MSH}$. Bound and unbound antiserum was separated with polyethylene glycol (final concentration: $7.5 \%$ ), or with a second antibody. Each sample was measured in duplicate.

\section{RESULTS}

\section{Immunocytochemistry With Anti-TRH}

Brain and pituitary tissue of 6 black-background adapted animals and of 6 white-background adapted animals were submitted to immunocytochemical analysis with anti-TRH. This revealed positively reacting cells in the hypothalamus and a neuronal tract which terminated in the median eminence and neural lobe area (Fig. 1a). This positive reaction was visible in tissue from both black- and white-adapted animals (Fig. 1b,c). No immunoreaction was observed in the pars intermedia of black-background adapted animals (Fig. 1c). However, occasionally the pars intermedia of white- 

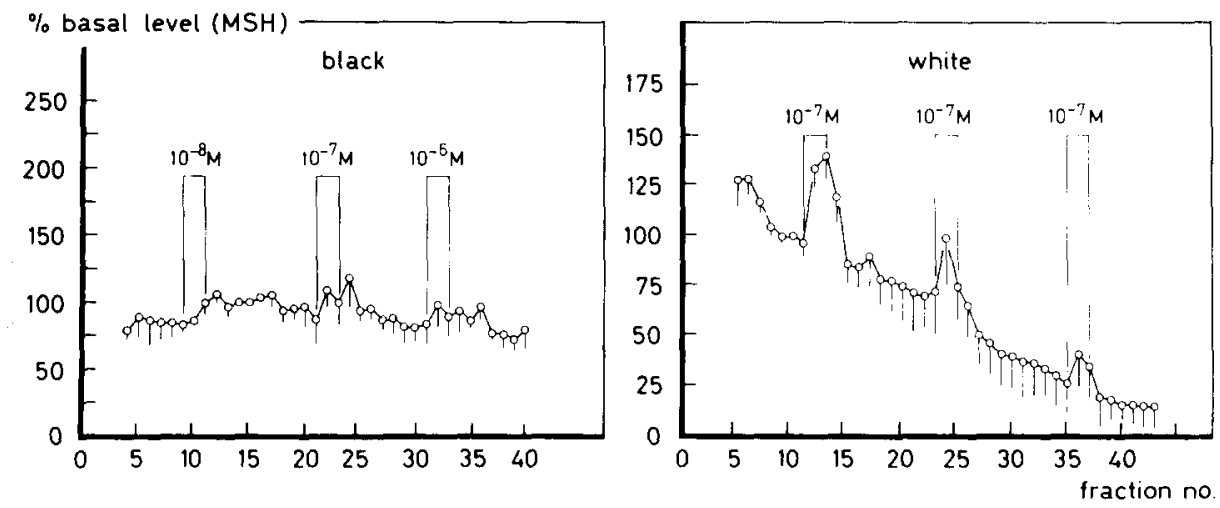

FIG. 3. Effect of TRH on basal release of MSH during in vitro superfusion of neurointermediate lobes of Xenopus laevis, which were previously adapted to either a black or a white background. Three 15-minute pulses of TRH were given; time periods and TRH concentrations administered are indicated in the figure. Each figure represents the average of three independent neurointermediate lobes. The $100 \%$ values for basal release were defined from the average value of MSH in fractions 14-16 for lobes of black-adapted animals and in fractions 8-11 for those of white-adapted animals. These values were $409,464,544 \mathrm{pg} \mathrm{MSH} / 7.5 \mathrm{~min}$ fraction, and 200, 246, $1432 \mathrm{pg} \mathrm{MSH} / 7.5 \mathrm{~min}$ fraction respectively. Vertical bars indicate -SEM.

adapted animals showed positive reaction in the intermediate lobe. An example of this is shown in Fig. 1a,b. This immunostaining was more diffuse than that observed in the neural lobe. No immunostaining was visible in the pars distalis of either black- or white-adapted animals.

\section{Radioimmunoassays for TRH}

The results of assays on plasma samples show a relatively high variation in TRH concentration in the blood of Xenopus (Table 1). With HPLC analysis, the TRH immunoreactive material in the plasma coeluted with synthetic TRH (Fig. 2). Plasma samples from black-background adapted animals contained a somewhat higher level of TRH than those of white-adapted animals, but these differences were not statistically significant. TRH levels in the pars distalis were very low, showing a higher content in lobes from blackbackground adapted animals. Neurointermediate lobes of both black- and white-adapted Xenopus laevis contained high levels of TRH. The levels found in black-adapted animals were slightly but not significantly higher than those measured for the lobes obtained from white-adapted animals.

\section{Effect of TRH on In Vitro Secretion of $M S H$}

The effects of 15 -min pulses of TRH on MSH secretion from neurointermediate lobes of both black- and whiteadapted animals were determined (Fig. 3). TRH appeared to be very effective in stimulating $\mathrm{MSH}$ release from lobes extirpated from white-adapted animals. Table 2 gives the dose-response relationship for TRH stimulation of secretion. Due to the phenomenon of declining baselines this relationship was determined with data from the first pulse of TRH and averaged from a number of superfusion experiments. The stimulatory response to TRH, displayed by lobes of white-adapted animals, was of rather short duration (Fig. 3). Occasionally the stimulatory effect was already declining during the 15 minutes of TRH administration.

Lobes from black-background adapted animals were in-
TABLE 2

DOSE-RESPONSE RELATIONSHIP FOR TRH-INDUCED STIMULATION OF MSH RELEASE FROM SUPERFUSED NEUROINTERMEDIATE LOBES OF WHITE-BACKGROUND ADAPTED Xenopus laevis

\begin{tabular}{lcc}
\hline & $\begin{array}{c}\text { \% Release } \\
( \pm \text { SEM })\end{array}$ \\
\hline TRH & $10^{-9} \mathrm{M}$ & $127 \pm 5(\mathrm{n}=3)^{*}$ \\
TRH & $10^{-8} \mathrm{M}$ & $151 \pm 6(\mathrm{n}=9)^{\ddagger}$ \\
TRH & $10^{-7} \mathrm{M}$ & $195 \pm 26(\mathrm{n}=6)^{\dagger}$ \\
TRH & $10^{-6} \mathrm{M}$ & $205 \pm 25(\mathrm{n}=6)^{\dagger}$ \\
MK771 & $10^{-7} \mathrm{M}$ & $171 \pm 14(\mathrm{n}=4)^{\ddagger}$ \\
\hline
\end{tabular}

TRH was administered during two consecutive 7.5 min periods. Basal release was defined as the average secretion of MSH during the three $7.5 \mathrm{~min}$ periods before TRH administration. Percent stimulation in relation to this value was calculated from the maximum amount of $\mathrm{MSH}$ released during the $15 \mathrm{~min}$ of TRH addition. Significant difference from control value as determined with the Student $t$-test $\left({ }^{*} p<0.05 ;{ }^{\dagger} p<0.001 ; \ddagger p<0.005\right)$.

sensitive to the neuropeptide (Fig. 3). To determine whether the unresponsiveness of lobes of black-background adapted animals could be attributed to the fact that in vitro $\mathrm{MSH}$ secretion of these lobes was already at maximum level, secretion was partially inhibitied by the addition of dopamine $\left(10^{-6} \mathrm{M}\right)$ prior to and during TRH administration. These lobes did not respond to TRH (Fig. 4).

One experiment was performed whereby the TRHinduced secretory response of neurointermediate lobe tissue of Rana ridibunda was tested to compare this response to that registered for Xenopus. The frogs were taken from a neutral grey background. Neurointermediate lobes of Rana could be stimulated by administration of TRH (Fig. 5). Already at $10^{-8} \mathrm{M}$ of TRH, $140 \%$ of the basal level of $\mathrm{MSH}$ secretion was observed. With increasing concentrations of TRH, this level increased to a maximum of $160 \%$ of basal secretion. Similar to Xenopus tissue, a rapid secretory re- 


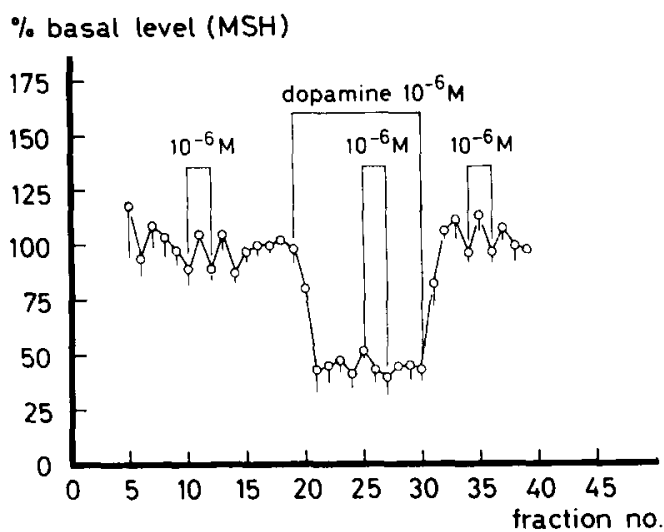

FIG. 4. Effect of TRH on secretion of MSH during in vitro superfusion of neurointermediate lobes of black-background adapted Xenopus laevis under basal and dopamine inhibited conditions. Fifteen-minute pulses of $10^{-6} \mathrm{M}$ TRH were given. Figure represents the average of three individual lobes. The $100 \%$ values of basal secretion were defined from the average $\mathrm{MSH}$-value in fractions 16-19; these were $462,549,975 \mathrm{pg}$ MSH/7.5 min fraction. Bars indicate - SEM.

sponse was noted, but the stimulatory effect of TRH on lobes of Rana was of a far longer duration. Following TRH administration, $45 \mathrm{~min}$ were required for $\mathrm{MSH}$ secretion to completely return to its basal level. The TRH analogue MK771 L-N(2-oxypiperidine-6-yl-carbonyl)-histidyl-thiazolidine-4carboxamide, was found to be potent in stimulating the in vitro release of MSH in lobes from white-adapted Xenopus (Table 2). Like TRH, MK771 caused a rapid increase in MSH release which was of short duration.

\section{DISCUSSION}

The tripeptide pGlu-His-Pro- $\mathrm{NH}_{2}$ received the name thyrotropin releasing hormone, TRH, for its stimulatory effect on secretion of thyrotropin from the pituitary gland of mammals. Indeed, in mammals it is probably the most important hypothalamic factor for regulation of thyrotropin release. In rat, TRH could not affect MSH secretion [21]. In cold-blooded vertebrates, TRH has no effect on the pituitary-thyroid axis $[11,36,41]$. It has, however, been shown to stimulate in vitro release of $\mathrm{MSH}$ from frog neurointermediate lobes [38] and prolactin from the bullfrog pars distalis [5]. Also, in vivo administration of TRH causes prolactin release in Rana ridibunda [17]. These observations suggest that this tripeptide may have evolved different functions during evolution. Interestingly, two different mammalian tumor cell lines have also been shown to respond to $\mathrm{TRH}$. In the rat $\mathrm{GH} 3$ cells the tripeptide stimulates prolactin release $[1,40]$, and it also stimulates secretion from cells of a human ACTH-producing ectopic tumor [3, 10, 15]. Therefore, this peptide seems to have a broad spectrum of potential activities. The present results demonstrate that in the neurointermediate lobe of the toad Xenopus laevis, TRH stimulates secretion of MSH in a dose-dependent manner, thus extending an earlier finding in the frog Rana ridibunda to a second amphibian species. While the amphibian TRH receptor has never been fully characterized, the toad pars intermedia proved to be sensitive to MK771, which is recognized as an equipotent TRH analogue $[18,23]$. Thus, on the basis of its in vitro effect on Xenopus melanotropes, TRH can

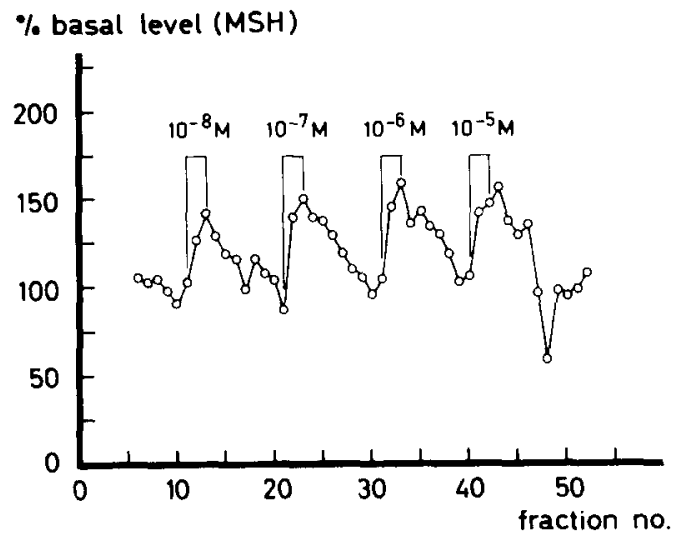

FIG. 5. Effect of TRH on basal secretion of MSH from neurointermediate lobes of Rana ridibunda, during in vitro superfusion. Fifteen-min pulses of $10^{-8}, 10^{-7}, 10^{-6}$ and $10^{-5} \mathrm{M}$ were given as indicated in the figure. Figure represents the average of two individual experiments. One hundred percent values of basal secretion were calculated from the average MSH-value in fractions 8-10; these were 180 and $116 \mathrm{pg} \mathrm{MSH} / 7.5 \mathrm{~min}$ fraction.

be considered a potential MSH release stimulating factor in this species.

A unique characteristic of the TRH-induced release of MSH secretion from the neurointermediate lobe of Xenopus is the observation that this tripeptide was effective in stimulating release from lobes of white-background but not black-background adapted animals. The simplest explanation for this phenomenon would be that melanotropes of black-background adapted animals are already releasing MSH at the maximum obtainable rate. We have found, however, that such lobes can be induced to higher levels of secretion through the use of a calcium inophore (unpublished observations), indicating that the release from these lobes is not at its maximum level. Moreover, the observation that TRH failed to stimulate secretion from dopamine-inhibited lobes of black-background adapted animals would also argue against this simple explanation. TRH receptors have been reported to undergo a very rapid ligand-induced desensitization $[4,29,33]$. Therefore, another possibility worth considering is that the TRH receptors in neurointermediate lobes of black-background adapted Xenopus are in a desensitized state.

The response of Xenopus neurointermediate lobe tissue to TRH was very short duration. Indeed, MSH release was often returning to basal level before TRH administration had even been terminated, a phenomenon not observed in earlier studies with Rana [38]. In view of this apparent difference in response between lobes of the two amphibian species, we decided to test lobes of Rana ridibunda under identical superfusion conditions as those for Xenopus. This study confirmed that the response of Rana lobes was indeed of much longer duration. In mammalian studies, TRH stimulation of thyrotropin release $[7,31]$ and prolactin release $[2,26]$ have been described as biphasic, consisting of a very rapid initial phase of hormone secretion, followed by a plateau of elevated secretion. It has been suggested that different intracellular mechanisms are responsible for the two phases of TRH-induced stimulation [2, 26, 34]. Interestingly, studies with rat thyrotropes [2] and $\mathrm{GH} 3$ tumor cells [34] indicate that the second phase of the response to TRH is dependent 
on protein synthesis. The melanotropes of white-background adapted Xenopus are known to have an extremely low level of biosynthetic activity $[19,24,48]$. This low biosynthetic capacity is probably responsible for the declining baseline of MSH release exhibited by lobes of white-background adapted animals (i.e., rate of release exceeds the rate of biosynthesis of the peptide). This point has been discussed in detail elsewhere [45]. Possibly, the observed absence of a sustained biphasic response to TRH by Xenopus lobes reflects their low biosynthetic capacity.

The results of the immunocytochemical analysis of TRH distribution in the hypothalamo-hypophyseal complex of Xenopus give an indication for a morphological basis for TRH regulation of the intermediate lobe. As the majority of the TRH positive neurons innervating the pituitary gland seems to terminate in varicosities of the neural lobe, TRH would presumably reach the melanotropes of the pars intermedia through extracellular diffusion from the pars nervosa, or alternatively, via the blood. Since the intermediate lobe is closely associated with the neural lobe tissue and, moreover, it receives its blood supply from this latter tissue, both mechanisms seem possible. In the pituitary gland of the frog Rana catesbeiana, Seki et al. [32] have found a similar distribution of TRH-immunoreactivity to that we now report for Xenopus. In addition, they describe a very scarce granular network of positive staining in the pars intermedia which demonstrates that at least some TRH-positive fibers are reaching the intermediate lobe. Occasionally, we observed a positive immunoreaction in the pars intermedia of Xenopus laevis but, from its very diffuse nature, we feel that it is unlikely that this staining represents nerve terminals. It could well be similar to the intracellular location of TRH that has been reported in the frog [27]. It is worth mentioning that the immunostaining of the pars intermedia, when observed, was found in lobes from white-background but not blackbackground adapted animals. Interestingly, the results of our superfusion experiments suggest that only the former lobes contain functional TRH-receptors.

The difference in neurointermediate lobe sensitivity to TRH between white- and black-background adapted animals and the differences in the immunocytochemical staining characteristics of their neurointermediate lobe tissue, raise the important question: is there a difference in the secretory activity of TRH-neurons innervating lobes of white- and black-background adapted Xenopus? In the expectation that a high rate of secretion might lead to an altered tissue content of TRH, we decided to quantify tissue levels of the peptide. These results, showing no significant difference in neurointermediate lobe levels of TRH between white- and black- adapted Xenopus, indicate that if differences in secretory activity exist in response to background color changes, this is not reflected in tissue levels of the peptide. Thus these data argue neither for, nor against, a physiological role for the TRH-neurons in the process of background adaptation.

Of critical importance in our evaluation of TRH as a potential regulatory factor of pars intermedia function, is the fact that amphibians are known to have high levels of this peptide in their skin and plasma $[6,30]$. The poison glands of the skin of Xenopus laevis have been shown to synthesize TRH [30]. In this species, the extremely high level of TRH in the skin, in combination with the observation that brain tissue contains a very low amount of this peptide, has led to the conclusion that plasma TRH is derived from the skin $[16,30]$. We too find high plasma values for TRH, but could find no significant difference in plasma TRH level between a blackand white-adapted animal. The observation that this plasma level is approximately $10^{-7} \mathrm{M}$, a concentration which is within the range of the dose-response relationship we established for this peptide, would indicate that for any regulatory role in the intermediate lobe, it would have to function at a relatively high concentration (above the plasma value of $10^{-7}$ M). Alternatively, the tissue might possess an enzymatic system for degradation of TRH so that melanotropes are not continuously exposed to the high circulating levels of TRH. In this respect it should be pointed out that intermediate lobe tissue is poorly vascularized [22], and thus one might expect a slow delivery of TRH from the blood.

In conclusion, while the presence of a rich TRH neuronal network within the neural lobe, and the demonstrated stimulatory effect this peptide has on MSH secretion, argue favourably for a physiological role of TRH in regulating the pars intermedia, some caution is necessary in defining the physiological role of TRH in Xenopus laevis. The peptide is capable of giving activation of MSH secretion in lobes of whitebackground adapted animals and thus, in this physiological state, or during the initial stages of adaptation to black background, it could be involved in adjusting the level of secretion. From our results it would seem doubtful that TRH has any regulatory role in the pars intermedia of fully blackbackground adapted X'nopus la'vis.

\section{ACKNOWLEDGEMENTS}

The authors wish to thank Mr. P. M. J. M. Cruijsen, Mr. Th. A. J. M. Coenen, Mr. W. Klootwijk and Mr. R. E. Engels for excellent technical assistance, and Mrs. E. M. Jansen-Hoorweg for her secretarial assistance. This work was supported by EEG grant No. STI084-5C.

\section{REFERENCES}

1. Aizawa, T. and P. M. Hinkle. Thyrotropin-releasing hormone rapidly stimulates a biphasic secretion of prolactin and growth hormone in $\mathrm{GH}_{4} \mathrm{C}_{1}$ rat pituitary tumor cells. Endocrinology 116: 73-82, 1985.

2. Albert, P. R. and A. H. Tashjian. Thyrotropin-releasing hormone-induced spike and plateau in cytosolic free $\mathrm{Ca}^{2+}$ concentrations in pituitary cells. J Biol Chem 259: 5827-5832, 1984.

3. Ambrosi, B., D. Bochicchio, A. Sartorio, M. Rondena and E. Riva. ACTH response to TRH and somatostatin in Nelson's syndrome. Horm Metab Res 14: 164, 1982.

4. Banerji, A. and C. Prasad. In vivo autoregulation of rat adenohypophyseal thyrotropin-releasing hormone receptor Life Sci 30: 2293-2299, 1982.
5. Clemons, G. K., S. M. Russel and C. S. Nicoll. Effects of mammalian thyrotropin-releasing hormone on prolactin secretion by bullfrog adenohypophysis in vitro. Gen Comp Endocrinol 38: 62-67, 1979.

6. Clothier, R. H., M. Balls, A. D. Wata, C. A. Marsden and G $\mathrm{W}$. Bennett. Location and synthesis of thyrotropin-releasing hormone and 5-hydroxytryptamine in the skin and thymus of Xenopus laevis. In: Thyrotropin-Releasing-Hormone, edited by E. C. Griffiths and G. W. Bennett. New York: Raven Press, 1983, pp. 203-216.

7. Connors, J. M., K. C. Wright, A. M. Judd, C. M. Lin and G. A. Hedge. Dynamics and regulation of TSH secretion by superfused anterior pituitary cells. Horm Res 14: 1-17, 1981. 
8. Cote, T. E., R. L. Eskay, E. A. Frey, C. W. Grewe, M. Munemura, J. C. Stoof, K. Tsuruta and J. W. Kebabian. Biochemical and physiological studies of the betaadrenoreceptor and the D-2 dopamine receptor in the intermediate lobe of the rat pituitary gland: A review. Neuroendocrinology 35: 217-224, 1982.

9. Eipper, B. A. and R. E. Mains. Structure and biosynthesis of pro-adrenocorticotropin/endorphin and related peptides. Endocr Rev 1: $1-27,1980$.

10. Gershengorn, M. C., C. O. Arevalo, E. Geras and M. J. Rebecchi. Thyrotropin-releasing hormone stimulation of adrenocorticotropin production by mouse pituitary tumor cells in culture. $J$ Clin Invest 65: 1294-1300, 1980.

11. Gona, A. G. and O. Gona. Failure of synthetic TRH to elicit metamorphosis in frog tadpoles or red-spotted newts. Gen Comp Endocrinol 24: 223-225, 1974.

12. Herbert, E. Discovery of pro-opiomelanocortin: a cellular polyprotein. Trends Biochem $S$ ci 6: 184-186, 1981.

13. Hogben, L. and D. Slome. The pigmentary effector system: VI. The dual character of endocrine coordination in amphibian color change. Proc $R$ Soc Lond [Biol] 108: 10-53, 1931.

14. Hopkins, C. R. Localization of adrenergic fibers in the amphibian pars intermedia by electron microscope autoradiography and their selective removal by 6-hydroxydopamine. Gen Comp Endocrinol 16: 112-120, 1971.

15. Ishibashi, M., T. Yamaji. Direct effects of thyrotropin-releasing hormone, cyproheptadine, and dopamine on adrenocorticotropin secretion from human corticotroph adenoma cells in vitro. $J$ Clin Invest 66: 1018-1027, 1981.

16. Jackson, I. M. D. and S. Reichlin. Thyrotropin-releasing hormone in the blood of the frog Rana pipiens: its nature and possible derivation from regional locations in the skin. Endocrinology 194: 1814-1821, 1979.

17. Kuhn, E. K., S. Kikuyama, R. Yamamoto and V. M. Darras. In vivo release of prolactin in Rana ridibunda following an intravenous injection of thyrotropin-releasing hormone. Gen Comp Endocrinol 60: 86-89, 1985.

18. Kruszynski, M., U. Ragnarsson, G. Kupryszewski, M. Alexandrova, V. Strbak, M. C. Tonon and H. Vaudry. TRH analogue with c-terminal thioamide group. Synthesis, receptor-binding, TSH and $\alpha-\mathrm{MSH}$ releasing activities. Experientia 14: 1576-1577. 1985.

19. Jenks, B. G., A. P. van Overbeeke and B. F. McStay. Synthesis, storage and release of MSH in the pars intermedia of the pituitary gland of Xenopus laevis during background adaptation. Can J Zool 55: 922-927, 1977

20. Jenks, B. G. Control of MSH synthesis and release in the aquatic toad, Xenopus laevis. In: Frontiers of Hormone Research, vol 4, edited by van Wimersma Greidanus. Basel: Karger, 1977, pp. 63-65.

21. Kraicer, J. Thyrotropin-releasing hormone does not alter the release of melanocyte-stimulating hormone or adrenocorticotropic hormone from the rat pars intermedia. Neuroendocrinology 24: 226-231, 1977.

22. Lametschwandtner, A., P. Simonsberger and H. Adam. Vascularization of the pars intermedia of the hypophysis in the toad, Bufo bufo. Cell Tissue Res 179: 11-16, 1977.

23. Leroux, P., M. C. Tonon, S. Jegou, F. Leboulenger, C. Delarue, I. Perroteau, P. Netchitailo, G. Kupryszewski and H. Vaudry. In vitro study of frog (Rana ridibunda pallas) neurointermediate lobe secretion by use of a simplified perifusion system. I. Effect of TRH analogs upon $\alpha$-MSH release. Gen Comp Endocrinol 46: 1-23, 1982.

24. Loh, Y. P. and H. Gainer. Biosynthesis, processing and control of release of melanotropic peptides in the neurointermediate lobe of Xenopus laevis. J Gen Physiol 70: 37-58, 1977.

25. Martens, G. J. M., B. G. Jenks and A. P. van Overbeeke. Biosynthesis of pairs of peptides related to melanotropin, corticotropin and endorphin in the pars intermedia of the amphibian pituitary gland. Eur J Biochem 122: 1-10, 1982.
26. Martin, T. F. J. and J. A. Kowalchyk. Evidence for the role of calcium and diacylglycerol as dual second messengers in thyrotropin-releasing-hormone action: involvement of diacylglycerol. Endocrinology 115: 1517-1526, 1984.

27. Morel, G., E. Leneveu, M. C. Tonon, G. Pelletier, H. Vaudry and P. M. Dubois. Subcellular localization of thyrotropinreleasing hormone (TRH)- and neuropeptide Y (NPY)-like immunoreactivity in the neurointermediate lobe of the frog pituitary. Peptides 6: 1085-1092, 1986.

28. Nakai, Y. and A. Gorbman. Evidence for a doubly innervated secretory unit in the anuran pars intermedia. Gen Comp Endocrinol 13: 108-116, 1969.

29. Peck, V. and G. Gerschengorn. Differential regulation of thyrotropin-releasing hormone receptors in neoplastic rodent mammotropic, adrenotropic and thyrotropic pituitary cells in culture. J Clin Endocrinol Metab 50: 1144-1146, 1980.

30. Richter, K., E. Kawashima, R. Egger and G. Kreil. Biosynthesis of thyrotropin releasing hormone in the skin of Xenopus laevis: partial sequence of the precursor deduced from cloned cDNA. EMBO J 3: 617-621, 1984

31. Schrey, M. P., B. L. Brown and R. P. Ekins. Studies on the control and dynamics of thyrotropin secretion from isolated adenohypophyseal cells. Mol Cell Endocrinol 8: 271-282, 1977.

32. Seki, T., Y. Nakai, S. Shioda, T. Mitsuma and S. Kikuyama. Distribution of immunoreactive thyrotropin-releasing hormone in the forebrain and hypophysis of the bullfrog, Rana catesbeiana. Cell Tissue Res 233: 507-516, 1983.

33. Sheppard, M. C. and K. I. J. Shennan. Desensitization of rat anterior pituitary gland to thyrotropin releasing hormone. $J$ Endocrinol 101: 101-105, 1984.

34. Shiota, K., K. Yoshida, T. Masaki, M. Kawase, R. Nakayama and $\mathrm{K}$. Sudo. Biphasic release of thyrotropin in response to thyrotropin-releasing hormone (TRH) from rat anterior pituitary cells in vitro: possible dependence on protein synthesis. Endocrinol I 31: 165-175, 1984.

35. Sternberger, L. A. Immunocytochemistry, 2nd edition. New York: Wiley, 1979.

36. Taurog, A., C. Oliver, R. Eskay, J. C. Porter and J. M. McKenzie. The role of TRH in the neoteny of the Mexican Axolotl (Ambystoma mexicanum). Gen Comp Endocrinol 24: $267-279,1974$.

37. Terlou, M., H. J. Th. Goos and P. G. W. J. van Oordt. Hypothalamic regulation of pars intermedia activity in amphibians. In: Fortschritte der Zoologie, vol 22, edited by $\mathbf{M}$. Lindauer. Stuttgart: Verlag, 1974, pp. 117-134.

38. Tonon, M. C., P. Leroux, F. Leboulanger, C. Delarue, S. Jegou and $\mathrm{H}$. Vaudry. Thyrotropin-releasing hormone stimulates the release of melanotropin from frog neurointermediate lobes in vitro. Life Sci 26: 869-875, 1980.

39. Tonon, M. C., P. Leroux, M. E. Stoeckel, S. Jegou, G. Pelletier and $H$. Vaudry. Catecholaminergic control of $\alpha$ melanocyte-stimulating hormone $(\alpha \mathrm{MSH})$ release by frog neurointermediate lobe in vitro: Evidence for direct stimulation of $\alpha \mathrm{MSH}$ release by thyrotropin-releasing-hormone. Endocrinology 112: 133-141, 1983.

40. Vale, W., J. Rivier and M. Brownstein. Regulatory peptides of the hypothalamus. Annu Rev Physiol 39: 473-527, 1977.

41. Vandesande, F. and M. Aspeslagh. Failure of thyrotropin releasing hormone to increase ${ }^{125} \mathrm{I}$ uptake by the thyroid in Rana temporaria. Gen Comp Endocrinol 23: 355-356, 1974.

42. Vandesande, F. Thesis. Rijksuniversiteit Gent, Belgium, 1978.

43. Vaudry, H., M. C. Tonon, C. Delarue, R. Vaillant and J. Kraicer. Biological and radioimmunological evidence for melanocyte stimulating hormones (MSH) of extrapituitary origin in the rat brain. Neuroendocrinology 27: 9-24, 1978.

44. Verburg-van Kemenade, B. M. L., M. Tappaz, L. Paut and B. G. Jenks. GABAergic regulation of melanocyte-stimulating hormone secretion from the pars intermedia of Xenopus laevis: Immunocytochemical and physiological evidence. Endocrinology 118: 260-267, 1986. 
45. Verburg-van Kemenade, B. M. L., B. G. Jenks and A. P. van Overbeeke. Regulation of melanotropin release from the pars intermedia of the amphibian Xenopus laevis: Evaluation of the involvement of serotonergic, cholinergic or adrenergic receptor mechanism. Gen Comp Endocrinol 63: 471-480, 1986.

46. Visser, Th. J., W. Klootwijk, R. Docter and G. Henneman. A new radioimmunoassay of the thyrotropin-releasing hormone. FEBS Lett 83: 37-40, 1977.
47. Visser, Th. J. and W. Klootwijk. Approaches to a markedly increased sensitivity of the radioimmunoassay for thyrotropinreleasing hormone by derivatization. B.B.A. 673: 454-466, 1981 .

48. Whur, P. and B. Weatherhead. Rates of incorporation of ${ }^{3} \mathrm{H}-$ leucine into protein of the pars intermedia of the pituitary in the amphibian Xenopus laevis after change of background color. $J$ Endocrinol 51: 521-532, 1971. 